\title{
Effect of cellulose acetate phthalate and polyethylene glycol on physical properties and release of theophylline from microcapsules
}

\author{
Amjad Hussain ${ }^{1}$, Ahmad Mehmood Mumtaz², Muhammad Sohail Arshad ${ }^{3}$, Nasir Abbas', \\ Abida Latif ${ }^{1}$, Rahat Shamim ${ }^{1}$, Nadeem Irfan Bukhari ${ }^{1}$, Khalid Hussain ${ }^{1, *}$ \\ ${ }^{1}$ University College of Pharmacy, University of the Punjab, Lahore, Pakistan, ${ }^{2}$ Ministry of Health Islamabad, Pakistan, \\ ${ }^{3}$ Department of Pharmacy, Bahauddin Zakariya University, Multan, Pakistan
}

\begin{abstract}
The present study describes the development of theophylline microcapsules by a non-solvent addition method and the effect of plasticizer addition on microencapsulation. The release was studied in distilled water and the data were analysed by various mathematical models for determining the mechanism of release. Prepared microcapsules were found to be spherical, free flowing and having more than $80 \%$ entrapped drug. The polymer - cellulose acetate phthalate and plasticizer - polyethylene glycol was considered to be affecting the properties of microcapsules including drug release (time for $50 \%$ drug release, $\mathrm{T}_{50}$ ). The formulation with the highest proportion of polymer and without plasticizer ( $\mathrm{F} 3$ ) showed the slowest release with $\mathrm{T}_{50}=4.3 \mathrm{~h}$, while the formulation with lower proportion of polymer and $20 \%(\mathrm{w} / \mathrm{w})$ plasticizer $(\mathrm{F} 13 \& 14)$ showed the fastest release of drug with $\mathrm{T}_{50}$ values of $1.2 \mathrm{~h}$ and $1.3 \mathrm{~h}$, respectively. The drug release from most of the formulations was found to be following Higuchi model. It is concluded from the results of the present study that cellulose acetate phthalate significantly affects the sustained release of the drug in water, whereas the addition of polyethylene glycol slightly enhances the drug release.
\end{abstract}

Uniterms: Theophylline/microcapsules. Microencapsulation. Cellulose acetate phthalate. Polyethylene glycol. Microcapsules/mechanism of release. Drugs/release.

O presente estudo descreve o desenvolvimento de microcápsulas de teofilina pelo método sem adição de solvente e o efeito da adição de plastificante na microencapsulação. A liberação foi estudada em água destilada e os dados foram analisados por vários modelos matemáticos para determinação do mecanismo de liberação. As microcápsulas preparadas mostraram-se esféricas, livres de corrente e com mais de $80 \%$ de fármaco encapsulado. O polímero - ftalato de acetato de celulose e o plastificante - polietileno glicol - afetaram as propriedades das microcápsulas, incluindo a liberação do fármaco (tempo para liberação de $50 \%$ do fármaco, $\mathrm{T}_{50}$ ). A formulação com a maior proporção de polímero e sem plastificante (F3) se mostrou como a de liberação mais lenta, com $\mathrm{T}_{50}=4,3 \mathrm{~h}$, enquanto as formulações com menor proporção de polímero e $20 \%$ de plastificante $(\mathrm{m} / \mathrm{m})(\mathrm{F} 13$ \& 14) apresentaram a liberação mais rápida do fármaco, com $\mathrm{T}_{50}$ de $1,2 \mathrm{~h}$ e 1,3 h, respectivamente. A liberação do fármaco para a maioria das formulações seguiu o modelo de Higuchi. Concluiu-se, dos resultados do presente estudo, que o ftalato do acetato de celulose afeta significativamente a liberação controlada do fármaco em água, enquanto que a adição de polietileno glicol aumenta ligeiramente a liberação do fármaco.

Unitermos: Teofilina/microcápsulas. Microencapsulação. Ftalato de acetato de celulose. Polietilenoglicol. Microcápsulas/mecanismo de liberação. Fármacos/liberação.

*Correspondence: Khalid Hussain. University College of Pharmacy. University of the Punjab. Lahore-54000, Pakistan. E-mail: khussain.pharmacy@pu.edu.pk, hussain_761@yahoo.com 


\section{INTRODUCTION}

Theophylline is an effective bronchodilator used for the treatment of chronic asthma and obstructive lung disease (Hendeles, Weinberger, 1983). The drug is under a narrow therapeutic index and has rapid and uniform absorption throughout the gastrointestinal tract (Ly, 1997). The conventionally used multiple dosing regimens of this drug results in adverse reactions that affect the gastrointestinal tract and the central nervous system. This is caused by the fluctuations of drug concentration in blood during the dosing intervals (Milavetz et al., 1984). Sustained-release theophylline formulations offer the advantage of less frequent dosing as well as minimum fluctuations in serum concentration during the dosing intervals as compared to conventional dosage forms. Thus, theophylline could be a candidate for a sustained release formulation.

The microencapsulation technique is an effective method for the preparation of oral sustained release dosage forms because the encapsulated drug is easier to administer and shows better compliance (Jalsenjak et al., 1976). Microcapsules are manufactured by various techniques including solvent-removal, hot-melt, solventevaporation, spray-coating, pan-coating, spray drying, phase-separation and coacervation (Madan, 1978). The non-solvent addition method has been frequently used by many researchers because it offers several advantages over the others particularly, coacervation and spray drying (Pongpaibul and Whitworth, 1986). Moreover, it is less time consuming and can be done at room temperature in the absence of water, thus suitable for water-sensitive active pharmaceutical ingredients.

For microencapsulation of drugs, cellulose acetate phthalate (CAP) has served as a polymer (Beyger and Nairn, 1986). It is an enteric polymer and is in need of a plasticizer in microencapsulation to improve its film forming characteristics. For such purposes, polyethylene glycol (PEG) is a frequently used (Rao, Diwan, 1997).

The present study was launched to prepare theophylline microcapsules using non-solvent addition method, and to evaluate the effect of different blends of the polymer and the plasticizer on the release of theophylline from microcapsule formulations.

\section{MATERIAL AND METHODS}

\section{Material}

Anhydrous theophylline (Beijing Infoark Taee, China), polyethylene glycol 6000 (PEG-6000) and cellulose acetate phthalate (China) were obtained from Pacific Pharmaceuticals (Pvt.) Ltd. Lahore, Pakistan. Magnesium stearate (E. Merck, Germany) was obtained from Flow Pharmaceuticals (Pvt.) Ltd. Analytical grade acetone, $n$-hexane and liquid paraffin (E. Merck, Germany) were purchased from the local market.

\section{Preparation of microcapsules}

Fifteen microcapsule theophylline formulations were prepared according to the composition shown in Table I using a method described by (Ahmad et al., 2012) with some modifications. Briefly, the polymer solution was prepared by soaking $2.0 \mathrm{~g}$ of CAP in $15 \mathrm{~mL}$ of acetone for $1 \mathrm{~h}$ in a beaker, covered with aluminum foil to avoid solvent evaporation, and then the contents were stirred for 10 to $15 \mathrm{~min}$. A fixed amount ( $1.0 \mathrm{~g})$ of theophylline was dispersed separately in varying amount of this polymer solution (Table I). Then each of the mixtures was mixed with $200 \mathrm{~mL}$ of liquid paraffin by stirring in a round bottom flask. The resulting dispersions were cooled to $10^{\circ} \mathrm{C}$. To each of the dispersions, $0.5 \mathrm{~g}$ of magnesium stearate was added while continuously stirring (locally made paddle) at 700 to $800 \mathrm{rpm}$ to prevent aggregation. Then $30 \mathrm{~mL}$ of $n$-hexane (as non-solvent) was added to the above dispersions. After $5 \mathrm{~min}$, microcapsules were separated by filtration and washed twice with $50 \mathrm{~mL}$ of $\mathrm{n}$-hexane and dried overnight at room temperature in desiccators. In the formulations F4 to F15, PEG was added in CAP solution in a ratio of 10, 20, 30 and 40\% (Table I). The PEG was added while stirring the polymer solution.

\section{Determination of percentage yield}

The yield of theophylline microcapsules was determined by the equation given as follows (Equation 1):

$$
\text { Yield }=\frac{\text { Weight of microcapsules }}{\text { Weight of solid ingredients }} \times 100 \quad \text { Equation } 1
$$

\section{Particle size}

The sieve method was used to identify the particle size of the prepared theophylline microcapsule formulations. A group of sieves (20, 40, 60, 80, 100 and 120 mesh size) were stacked and $10 \mathrm{~g}$ of microcapsules were placed on the top screen and vibrated mechanically for $10 \mathrm{~min}$. The amount of microcapsules on each screen was determined by weighing and the mean particle size was calculated from the percentage weight retained and mean of openings of the sieve. 
TABLE I - Composition of formulations with drug, polymer and plasticizer

\begin{tabular}{lccc}
\hline Formulation & $\begin{array}{c}\text { Polymer } \\
\text { CAP. }(\text { g) }\end{array}$ & $\begin{array}{c}\text { Plasticizer } \\
\text { (g) }\end{array}$ & $\begin{array}{c}\text { CAP to PEG } \\
\text { Ratio }\end{array}$ \\
\hline F1 & 1 & 0 & $1: 0$ \\
F2 & 2 & 0 & $2: 0$ \\
F3 & 3 & 0 & $3: 0$ \\
F4 & 1 & 0.1 & $1: 0.1$ \\
F5 & 2 & 0.1 & $2: 0.1$ \\
F6 & 3 & 0.1 & $3: 0.1$ \\
F7 & 1 & 0.2 & $1: 0.2$ \\
F8 & 2 & 0.2 & $2: 0.2$ \\
F9 & 3 & 0.2 & $3: 0.2$ \\
F10 & 1 & 0.3 & $1: 0.3$ \\
F11 & 2 & 0.3 & $2: 0.3$ \\
F12 & 3 & 0.3 & $3: 0.3$ \\
F13 & 1 & 0.4 & $1: 0.4$ \\
F14 & 2 & 0.4 & $2: 0.4$ \\
F15 & 3 & 0.4 & $3: 0.4$ \\
\hline
\end{tabular}

CAP (cellulose acetate phthalate); PEG (polyethylene glycol)

\section{Measurement of flowability}

The angle of repose was measured using funnel with fixed-base cone. Carr's index was established using the tapped and bulk density. The tapped density was determined by loading $2 \mathrm{~g}$ of microcapsules in a $10 \mathrm{~mL}$ measuring cylinder. The cylinder was tapped by dropping it three times freely from a height of $5 \mathrm{~cm}$ onto the desktop. The measured volume was recorded and bulk density was calculated using equation, $\mathrm{d}=\mathrm{m} / \mathrm{v}$, where $\mathrm{d}, \mathrm{m}$ and $\mathrm{v}$ are tapped density, weight and volume of microcapsules, respectively.

\section{Determination of drug content}

Standard stock solution $(100 \mu \mathrm{g} / \mathrm{mL})$ was prepared by dissolving $10 \mathrm{mg}$ of theophylline in $10 \mathrm{~mL}$ of sodium hydroxide solution $(0.1 \mathrm{~N})$ in a $100 \mathrm{~mL}$ volumetric flask and then making up the volume with distilled water. The working standard solutions having a concentration 20 , 40,60 , and $80 \mu \mathrm{g} / \mathrm{mL}$ were prepared by diluting the stock solution with distilled water.

Microcapsules of each formulation equivalent to $10 \mathrm{mg}$ were dissolved in $10 \mathrm{~mL}$ of sodium hydroxide solution $(0.1 \mathrm{~N})$ in a $100 \mathrm{~mL}$ volumetric flask and volume was made up with distilled water. The working sample solution of each of the samples was prepared by taking
$40 \mathrm{~mL}$ of the stock solution in a $100 \mathrm{~mL}$ volumetric flask and making up the volume with distilled water.

All the standard and sample solutions were analyzed in triplicate using spectrophotometer at $271.2 \mathrm{~nm}$. The contents of theophylline of microcapsule formulations were determined from the calibration curve using the linear regression equation.

\section{In-vitro dissolution test}

Dissolution tests were performed in $900 \mathrm{~mL}$ deionized water using USP basket method-II with rotation speed of $100 \mathrm{rpm}$ at $37 \pm 0.5^{\circ} \mathrm{C}$. Microcapsules equivalent to $100 \mathrm{mg}$ theophylline was placed into baskets. The aliquots of $10 \mathrm{~mL}$ were withdrawn at regular intervals $(15,30,60,90,120,150 \mathrm{~min})$ and replaced with an equal volume of fresh medium. All the samples were filtered, diluted sufficiently and the UV absorbance was determined at $\lambda \max$ of $271.2 \mathrm{~nm}$. All the samples were analyzed in triplicate $(n=3)$ and the contents of theophylline were determined from the calibration curve.

\section{Time for $50 \%$ of drug released $\left(T_{50}\right)$}

$\mathrm{T}_{50}$ - time taken by any formulation to release $50 \%$ of its active contents in the dissolution media - was based on the release profile of each formulation taking the time against $50 \%$ release.

\section{Release kinetics analysis}

Three kinetic models such as zero order (Equation.3), first order (Equation 4) and Higuchi model (Equation 5) were implemented to analyze in-vitro release data to find the equation which best described the data based on highest $\mathrm{R}^{2}$.

$$
\begin{array}{cc}
\mathrm{Q}_{\mathrm{t}}=\mathrm{K}_{1} \mathrm{t} & \text { Equation 2 } \\
\ln \mathrm{Q}_{\mathrm{t}}=\ln \mathrm{Q}_{\mathrm{o}}-\mathrm{K}_{2} \mathrm{t} & \text { Equation 3 } \\
\mathrm{Q}=\mathrm{K}_{3}(\mathrm{t})^{0.5} & \text { Equation 4 }
\end{array}
$$

where $\mathrm{Q}$ is release percentage at time $\mathrm{t}$, and $\mathrm{K}_{1}, \mathrm{~K}_{2}$ and $\mathrm{K}_{3}$ are the rate constants of zero order, first order and Higuchi model, respectively.

For the mechanism of drug release, the RitgerPeppas model (Equation 6) was also employed (Higuchi, 1963).

$$
\mathrm{M}_{\mathrm{t}} / \mathrm{M}_{\infty}=\mathrm{kt}^{\mathrm{n}} \quad \text { Equation } 5
$$

where $M_{t} / M_{\infty}$ is the fraction of drug released at time $t, k$ is a 
proportionality constant, which accounts for the structural and geometrical properties of the polymer matrix, and $\mathrm{n}$ is the diffusional exponent indicative of the mechanism of drug release (Washington, 1996).

\section{RESULTS AND DISCUSSION}

Microcapsules of theophylline were prepared using different blends of CAP as polymer and PEG as plasticizer. The yield of all formulations was above $75 \%$ (Table II). The developed microcapsules were characterized in term of particle size, density, flowability, drug content, release and time for $50 \%$ drug release $\left(\mathrm{T}_{50} \%\right)$.

\section{Physical properties of formulations}

The physical properties of theophylline microcapsules have been provided in Table II. The particle size of formulations decreased upon increasing the polymer ratio in F1 to F3. The higher contents of the polymer increased in viscosity of polymeric solution producing smaller sized microcapsules. These findings are consistent with that reported earlier (Sanghvi, Nairn, 1991; Song et al., 2005). However, in formulations containing plasticizer (F4 to F15), the particle size increase (Table II) with the concentration of the plasticizer. This increase in particle size was caused by plasticizer induced moisture uptake by the polymer wall (Wan et al., 1993). The angle of repose $\leq 25^{\circ}$ of all the microcapsules formulations indicate good flowability which is also depicted in the value of Carr index i.e. $<15$ in all microcapsule formulations. All the formulations have exhibited good drug entrapment efficiency, greater than $80 \%$ in all formulations, except F7 which might not be the real effect.

\section{Drug release}

Five standard solutions of theophylline were analysed in triplicate and the absorbance of these solutions was plotted against the respective concentration to construct the calibration curve. The linear regression equation determined from the calibration curve was found to be $\mathrm{Y}=0.0047 \mathrm{X}+0.0874\left(\mathrm{R}^{2}=0.9923\right)$. This equation was used to calculate the drug contents realsed from the microcapsule formulations at different time intervals. As shows in Figure1, the release of theophylline from microcapsules decreased gradually by increasing drug to polymer ratio of $1: 1$ to $1: 3$ in formulation $F 1$ to $F 3$ (Figure 1). This effect is ascribed to the better covering of drug particles by the polymer (Goosen et al., 1985). The F3 showed only $12 \%$ release while F13 and F14 exhibited approximately $50 \%$ release in the first one hour. The formulations F13 and F14 released the drug most rapidly from all the microcapsule formulations (Figure 1). The inclusion of plasticizer produced channels in the polymer film of microcapsules (Palomo et al., 1996). In this study

TABLE II - Physical properties of theophylline microcapsule formulations

\begin{tabular}{lccccccc}
\hline Formulation & $\begin{array}{c}\text { Drug/Polymer } \\
\text { ratio }\end{array}$ & $\begin{array}{c}\text { Plasticizer } \\
(\mathbf{\%})\end{array}$ & $\begin{array}{c}\text { Mean particle } \\
\text { size }(\boldsymbol{\mu m})\end{array}$ & $\begin{array}{c}\text { Density } \\
\text { (Tapped) }\end{array}$ & $\begin{array}{c}\text { Drug content/ } \\
\text { Yield (\%) }\end{array}$ & $\begin{array}{c}\text { Carr } \\
\text { Index }\end{array}$ & $\begin{array}{c}\text { Angle of } \\
\text { repose }\end{array}$ \\
\hline F1 & $1: 1$ & 0 & 318 & 0.476 & 79.2 & 4.55 & 20 \\
F2 & $1: 2$ & 0 & 257 & 0.429 & 85.9 & 3.16 & 21 \\
F3 & $1: 3$ & 0 & 266 & 0.512 & 97.9 & 2.50 & 22 \\
F4 & $1: 1$ & 10 & 499 & 0.421 & 79.3 & 1.16 & 22 \\
F5 & $1: 2$ & 10 & 512 & 0.481 & 87 & 3.49 & 23 \\
F6 & $1: 3$ & 10 & 242 & 0.530 & 93 & 3.85 & 22 \\
F7 & $1: 1$ & 20 & 320 & 0.487 & 73.2 & 3.53 & 23 \\
F8 & $1: 2$ & 20 & 302 & 0.476 & 79.5 & 3.45 & 24 \\
F9 & $1: 3$ & 20 & 297 & 0.434 & 92.4 & 4.17 & 23 \\
F10 & $1: 1$ & 30 & 344 & 0.500 & 85.5 & 6.98 & 22 \\
F11 & $1: 2$ & 30 & 289 & 0.487 & 78.5 & 4.65 & 25 \\
F12 & $1: 3$ & 30 & 314 & 0.481 & 88 & 2.35 & 21 \\
F13 & $1: 1$ & 40 & 394 & 0.465 & 80.9 & 6.52 & 22 \\
F14 & $1: 2$ & 40 & 259 & 0.459 & 84.8 & 3.33 & 23 \\
F15 & $1: 3$ & 40 & 266 & 0.454 & 92.8 & 2.22 & 23 \\
\hline
\end{tabular}


channeling effect of plasticizer caused the increased release from microcapsules. The time of $50 \%$ drug release was prolonged almost linearly with an increase in drug to polymer ratio from F1 to F3 (Table III). The higher amount of polymer provided thick coating thus caused slow release of drug (Jalil and Nixon, 1990). However, $\mathrm{T}_{50}$ for formulations containing plasticizer was found to be decreasing as compared to formulations without plasticizer. This was due to the swelling and hydration of the polymer film and development of pores on the wall of microcapsules secondary to leach of the plasticizer (Merkle, Speiser, 1973).

\section{Kinetics analysis of release study}

The release data were submitted to zero order, first
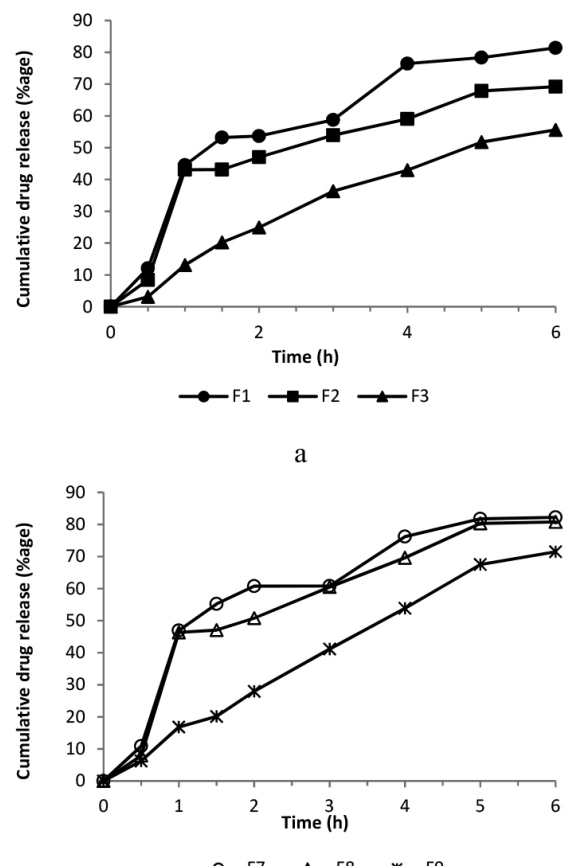

$\mathrm{c}$

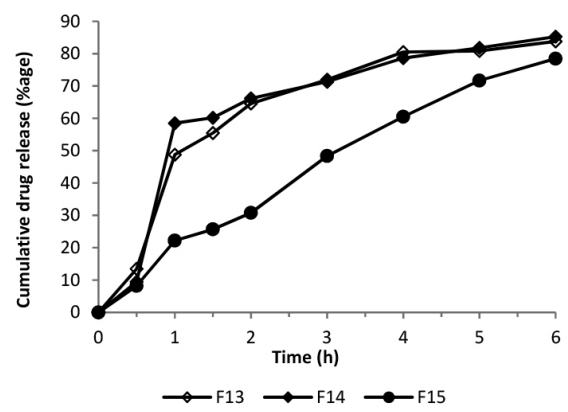

order, Higuchi's and Peppas model (Reddy et al., 2003, $\mathrm{Wu}$ et al., 2003). The release model parameters for all the formulations are shown in Table IV. The release of formulation F1 and F2 followed the Higuchi square root model with $\mathrm{R}^{2}$ values 0.9353 and 0.9134 , respectively. The values of $\mathrm{n}$ from Peppas model for these formulations were 0.2377 and 0.2968 , respectively $(\mathrm{n}<5)$, which indicated that the drug release for F1 and F2 followed the Fickian diffusion (Li et al., 2006, Hossain et al., 2007). The release from $\mathrm{F} 3$ followed zero order $\left(\mathrm{R}^{2}=0.9714\right)$ and the $\mathrm{n}$ value of Peppas model was $0.8068(n>5)$ which indicated a non-Fickian or anomalous release. These results were in agreement with the findings of previous studies (Ritger, Peppas, 1987; Majid Khan, Zhu, 1999).

The increase of 10 to $40 \%$ concentration of plasticizer in formulation F4 to F15 did not essentially

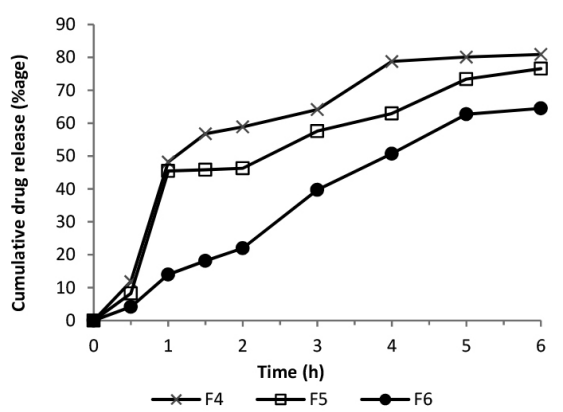

b

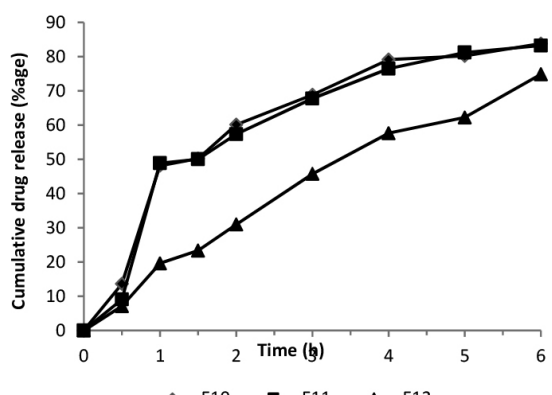

d

$\mathrm{e}$

FIGURE 1 - Drug release profile of different theophylline microcapsule formulations a) F1-F3 (no plasticizer) b) F4-F6 (10\% plasticizer), c) F7-F9 (20\% plasticizer), d) F10-F12 (30\% plasticizer) e) F13-F15 (40\% plasticizer). 
change the mechanism of drug release as all the formulations with drug to polymer ratio 1:1 and 1:2 (with or without plasticizer) followed the Higuchi model and the mechanism according to Peppas model was Fickian diffusion. The formulation with drug to polymer ratio

TABLE III - Time for $50 \%$ drug release and cumulative \%age of drug released in $6 \mathrm{~h}$

\begin{tabular}{lcc}
\hline Formulation & $\mathbf{T}_{\mathbf{5 0}}(\mathbf{h}) \mathbf{( \pm \mathbf { S D } )}$ & $\begin{array}{c}\text { Total drug released } \\
\text { in } \mathbf{6} \mathbf{~ h}(\mathbf{\%})\end{array}$ \\
\hline F1 & $2.4 \pm 0.1$ & 81 \\
F2 & $3.2 \pm 0.15$ & 69 \\
F3 & $4.8 \pm 0.2$ & 56 \\
F4 & $2.2 \pm 0.1$ & 81 \\
F5 & $2.8 \pm 0.1$ & 77 \\
F6 & $4.2 \pm 0.2$ & 64 \\
F7 & $2.4 \pm 0.15$ & 82 \\
F8 & $2.6 \pm 0.15$ & 81 \\
F9 & $3.6 \pm 0.2$ & 71 \\
F10 & $2.2 \pm 0.1$ & 84 \\
F11 & $2.4 \pm 0.1$ & 83 \\
F12 & $3.6 \pm 0.15$ & 75 \\
F13 & $1.2 \pm 0.1$ & 84 \\
F14 & $1.3 \pm 0.1$ & 85 \\
F15 & $3.4 \pm 0.2$ & 78 \\
\hline
\end{tabular}

1:3 (with or without plasticizer) followed the zero order release with non-Fickian or anomalous release mechanism.

It appeared that all the formulations followed the kinetics, which could not be explained by a single model. Kinetic profile during the first hour was usually the first order, which probably represented the nonencapsulated fraction of drug. Then another profile (Higuchi or zero order) after $1 \mathrm{~h}$ indicated the release of the drug by diffusion, erosion or by the combination of both mechanisms as shown by ' $n$ ' values). Possibly there is more than one mechanism involved, and it seems that the effect of polymer concentration is more pronounced as compared to the percentage of plasticizer in each formulation. This argument is supported by the experimental data indicating more or less similar release profiles of the formulations (F3, F6, F9, F12 and F15) having an increasing concentration of the plasticizer and keeping drug to polymer ratio constant (1:3).

\section{CONCLUSION}

In this study, the microcapsules of theophylline were prepared using a non-solvent addition method. The microcapsules have shown better entrapment efficiency of drug and other processing properties. It is also concluded that the rate of drug release is inversely related to the polymer concentration. The addition of plasticizer slightly enhances the drug release.

TABLE IV - Kinetic values obtained from different plots of theophylline microcapsule formulations

\begin{tabular}{lcccccccc}
\hline \multirow{2}{*}{ Formulation } & \multicolumn{2}{c}{ Zero order } & \multicolumn{2}{c}{ First order } & \multicolumn{2}{c}{ Higuchi } & \multicolumn{3}{c}{ Peppas } \\
\cline { 2 - 9 } & $\mathbf{K}$ & $\mathbf{R}^{\mathbf{2}}$ & $\mathbf{K}$ & $\mathbf{R}^{\mathbf{2}}$ & $\mathbf{K}$ & $\mathbf{R}^{2}$ & $\mathbf{n}$ & $\mathbf{R}^{\mathbf{2}}$ \\
\hline F1 & 12.335 & 0.807 & 0.4739 & 0.4758 & 35.356 & 0.9353 & 0.2377 & 0.9054 \\
F2 & 10.299 & 0.777 & 0.4672 & 0.4804 & 29.729 & 0.9134 & 0.2968 & 0.9445 \\
F3 & 9.63 & 0.9714 & 0.5535 & 0.699 & 25.387 & 0.953 & 0.8068 & 0.9909 \\
F4 & 12.235 & 0.7561 & 0.4714 & 0.4585 & 35.748 & 0.9106 & 0.2519 & 0.948 \\
F5 & 11.462 & 0.8072 & 0.4839 & 0.4944 & 32.64 & 0.9224 & 0.2534 & 0.8306 \\
F6 & 11.658 & 0.9808 & 0.5756 & 0.7416 & 30.09 & 0.9218 & 0.9395 & 0.9811 \\
F7 & 12.46 & 0.7741 & 0.4788 & 0.4697 & 36.086 & 0.9161 & 0.2422 & 0.8456 \\
F8 & 12.551 & 0.8226 & 0.499 & 0.5041 & 35.355 & 0.9314 & 0.3046 & 0.9062 \\
F9 & 12.426 & 0.9889 & 0.554 & 0.707 & 32.188 & 0.9362 & 0.8967 & 0.9876 \\
F10 & 12.678 & 0.7909 & 0.471 & 0.4634 & 36.718 & 0.9359 & 0.3442 & 0.931 \\
F11 & 12.853 & 0.7903 & 0.4937 & 0.4862 & 36.986 & 0.9234 & 0.3089 & 0.9068 \\
F12 & 12.285 & 0.9804 & 0.5362 & 0.6653 & 32.274 & 0.9547 & 0.7803 & 0.9845 \\
F13 & 12.573 & 0.7504 & 0.4689 & 0.4512 & 36.952 & 0.9145 & 0.4001 & 0.9789 \\
F14 & 12.332 & 0.6866 & 0.4802 & 0.4452 & 36.719 & 0.8588 & 0.1717 & 0.8501 \\
F15 & 13.4 & 0.9825 & 0.5369 & 0.6555 & 34.64 & 0.9532 & 0.7594 & 0.9614 \\
\hline
\end{tabular}




\section{ACKNOWLEDGMENTS}

The authors are thankful to M/S Flow Pharmaceuticals (Pvt.) Ltd., Sheikhupura Road, Lahore, Pakistan and M/S Pacific Pharmaceuticals (Pvt.) Ltd. Lahore, Pakistan for gifting materials and extending laboratory facilities for this study.

\section{REFERENCES}

AHMAD, M.; AKHTAR, N.; MURTAZA, G.; HUSSAIN, S.W. Formulation development and in vitro evaluation of theophylline microcapsules. Pak. J. Pharm. Sci., v.25, n.1, p.15-19, 2012.

BEYGER, J.W.; NAIRN, J.G. Some factors affecting the microencapsulation of pharmaceuticals with cellulose acetate phthalate. J. Pharm. Sci., v.75, n.6, p.573-578, 1986.

GOOSEN, M.F.A.; O'SHEA, G.M.; GHARAPETIAN, H.M.; CHOU, S.; SUN, A.M. Optimization of microencapsulation parameters: semipermeable microcapsules as a bioartificial pancreas. Biotechnol. Bioeng., v.27, n.2, p.146-150, 1985.

HENDELES, L.; WEINBERGER, M. Theophylline. A" state of the art" review. Pharmacotherapy, v.3, n.1, p.2-44, 1983.

HIGUCHI, T. Mechanism of sustained-action medication: theoretical analysis of rate of release of solid drugs dispersed in solid matrices. J. Pharm. Sci., v.52, n.12, p.1145-1149, 1963.

JALIL, R.; NIXON, J. Biodegradable poly (lactic acid) and poly (lactide-co-glycolide) microcapsules: problems associated with preparative techniques and release properties. $J$. Microencapsul., v.7, n.3, p.297-325, 1990.

JALSENJAK, I.; NICOLAIDOU, C.F.; NIXON, J. The in vitro dissolution of phenobarbitone sodium from ethyl cellulose microcapsules. J. Pharm. Pharmacol., v.28, n.12, p.912914, 1976.

LY, J.P.-H. Development of an oral microspherical formulation for bimodal in vitro release of theophylline. Toronto, 1997. 87 p. [Thesis of Master of Science Degree - Graduate Department of Pharmaceutical Sciences - University of Toronto].

MADAN, P. Microencapsulation I. Phase separation or coacervation. Drug Dev. Ind. Pharm., v.4, n.1, p.95-116, 1978.
MAJID, K.G.; ZHU, J.B. Studies on drug release kinetics from ibuprofen-carbomer hydrophilic matrix tablets: influence of co-excipients on release rate of the drug. J. Control. Release, v.57, n.2, p.197-203, 1999.

MERKLE, H.; SPEISER, P. Preparation and in vitro evaluation of cellulose acetate phthalate coacervate microcapsules. $J$. Pharm. Sci., v.62, n.9, p.1444-1448, 1973.

MILAVETZ, G.; WEINBERGER, M.; VAUGHAN, L. Dose dependency for absorption and elimination rates of theophylline implications for studies of bioavailability. Pharmacotherapy, v.4, n.4, p.216-220, 1984.

PALOMO, M.; BALLESTEROS, M.; FRUTOS, P. Solvent and plasticizer influences on ethylcellulose-microcapsules. $J$. Microencapsul., v.13, n.3, p.307-318, 1996.

PONGPAIBUL, Y.; WHITWORTH, C. Preparation and in vitro dissolution characteristics of propranolol microcapsules. Int. J. Pharm., v.33, n.1/3, p.243-248, 1986.

RAO, P.R.; DIWAN, P.V. Permeability studies of cellulose acetate free films for transdermal use: influence of plasticizers. Pharm. Acta Helv., v.72, n.1, p.47-51, 1997.

REDDY, K.R.; MUTALIK, S.; REDDY, S. Once-daily sustained-release matrix tablets of nicorandil: formulation and in vitro evaluation. AAPS PharmSciTech, v.4, n.4, art.61, p.1-9, 2003.

RITGER, P.L.; PEPPAS, N.A. A simple equation for description of solute release II. Fickian and anomalous release from swellable devices. J. Control. Release, v.5, n.2, p.37-42, 1987.

SANGHVI, S.P.; NAIRN, J.G. Phase diagram studies for microencapsulation of pharmaceuticals using cellulose acetate trimellitate. J. Pharm. Sci., v.80, n.4, p.394-398, 1991.

SONG, M.; LI, N.; SUN, S.; TIEDT, L.R.; LIEBENBERG, W.; DE VILLIERS, M.M. Effect of viscosity and concentration of wall former, emulsifier and pore-inducer on the properties of amoxicillin microcapsules prepared by emulsion solvent evaporation. Farmaco, v.60, n.3, p.261-267, 2005.

WAN, L.; HENG, P.; CHIA, C. Citric acid as a plasticizer for spray-dried microcapsules. J. Microencapsul., v.10, n.1, p.11-23, 1993. 
WASHINGTON, C. Drug release from microparticulate systems. In: BENITA, S., ed. Microencapsulation: methods and industrial applications. New York: Marcel Dekker, 1996. p.155-181. (Drugs and the Pharmaceutical Sciences, v.73).
WU, P.C.; HUANG, Y.B.; CHANG, J.I.; TSAI, M.J.; TSAI, Y.H. Preparation and evaluation of sustained release microspheres of potassium chloride prepared with ethylcellulose. Int. J. Pharm., v.260, n.1, p.115-121, 2003.

Received for publication on $27^{\text {th }}$ March 2015 Accepted for publication on $28^{\text {th }}$ October 2015 